\title{
Polyembryony and identification of Volkamerian lemon zygotic and nucellar seedlings using RAPD
}

María Andrade-Rodríguez ${ }^{(1)}$, Angel Villegas-Monter(1), Guillermo Carrillo-Castañeda( ${ }^{(1)}$, and Armando García-Velázquez ${ }^{(1)}$

(1)Colegio de Postgraduados en Ciencias Agrícolas, Instituto de Recursos Genéticos y Productividad. Código postal 56230, Montecillo Estado de México. México. E-mail: avillega@colpos.mx, andradem65@hotmail.com

Abstract - The objectives of this work were to evaluate the frequency of polyembryony, and to identify zygotic and nucellar seedlings of Citrus volkameriana using RAPD. Twenty-five polyembryonic and eight monoembryonic seeds were cultivated in vitro for six months. DNA from seedlings was extracted and used in combination with five RAPD primers to identify zygotic or nucellar origin of the seedlings. Environmental conditions of the year affected significantly $(\mathrm{P} \leq 0.05)$ the morphological characteristics of fruits and the number of embryos per seed. Polyembryonic seeds ranged from 30.9\%, $44.8 \%$ to $54.4 \%$ over three years. Morphological characteristic was not correlated with polyembryony. In vitro culture enable all embryos of each seed to grow, favoring the percentage of seedlings identified as zygotic. In polyembryonic and monoembryonic seeds, $25.9 \%$ and $87.5 \%$ of the seedlings, respectively, were sexually originated. In polyembryonic seeds, not all zygotic seedlings were produced by small embryos located at the micropyle.

Index terms: Citrus volkameriana, rootstock, embryo culture, molecular markers, polymorphism.

\section{Poliembrionia e identificação de seedlings zigóticos e nucelares de limão volkameriano com RAPD}

Resumo - Os objetivos deste trabalho foram avaliar a freqüência da poliembrionia e indentificar os seedlings zigóticos e nucelares de Citrus volkameriana usando RAPD. Cultivaram-se in vitro 25 sementes poliembriônicas e 8 monoembriônicas, por seis meses. Extraiu-se o DNA dos seedlings e usou-se em combinação com cinco primers RAPD para identificar a origem zigótica e nucelar das plântulas. Os resultados mostraram que as condições ambientais do ano afetaram significativamente $(\mathrm{P} \leq 0,05)$ as características morfológicas dos frutos e o número de embriões por semente. Os índices de sementes poliembriônicas variaram nos três anos de avaliação $(30,9 \%, 44,8 \%$ e 54,4\%). As características morfológicas não se correlacionaram com a poliembrionia. A cultura in vitro possibilita que todos os embriões de cada semente cresçam, favorecendo os seedlings identificados como zigóticos. Nas sementes poliembriônicas e monoembriônicas, $25,9 \%$ e $87,5 \%$ dos seedlings, respectivamente, originaram-se sexualmente. Nem todos os seedlings zigóticos foram produzidos por embriões localizados no micrófilo das sementes poliembriônicas.

Termos para indexação: Citrus volkameriana, porta-enxerto, cultura de embriões, marcadores moleculares, polimorfismo.

\section{Introduction}

In Mexico, nearly $90 \%$ of all citrus plantations are grafted onto Citrus aurantium L., even though the use of this species as a rootstock may produce plants vulnerable to citrus tristeza virus (CTV). This, along with the presence of the disease and its vector, may cause great risk to the citriculture in Mexico, therefore leading to significant losses in crop production, such as reported for Argentina, Brazil, and more recently, Venezuela (Villegas et al., 2000).

Replacing sour orange with tristeza tolerant rootstocks is a technique used in countries where this problem has arisen, in order to guarantee citrus fruit production. However, recently, there have not been enough rootstocks seeds to produce tristeza tolerant plants, in order to carry this task. Citrus volkameriana Pascuale, along with the trifoliates 'Troyer' citrange, 'Carrizo' citrange, 'Swingle' citrumelo, C. reshni and C. amblycarpa may be alternatives.

Citrus plants grafted onto C. volkameriana are vigorous, extremely productive, salt tolerant and grow in calcareous, sandy or clayish soils; they are tolerant to CTV, Phytophthora parasitica (Pompeu Junior, 1991) and exocortis (Castle, 1987). 
Citrus polyembryony can be used to propagate plants through nucellar embryos. Like most citrus trees, C. volkameriana displays polyembryony, i.e., growth of two or more embryos in a single seed, one of sexua origin and the rest of somatic origin (nucellar). Embryo rescue is important to produce clones that may be tolerant to the tristeza virus. This process is fast and may produce the amount of plants required by the citrus industry, because the embryos are already formed.

Identifying the sexual embryo in each hybrid seed, in order to preserve only the nucellar ones, would help to maintain the genetic characteristics of the rootstock. This selection process could be performed by the examination of morphological characteristics, but only after these hybrids have produced their first fruit (four to seven years after planting), unless a seedling trait such as trifoliate leaves is available.

For a more rapid advance in the propagation program, it is necessary to identify zygotic seedlings at an early stage (as a seedling) and for this purpose, several biochemical methods have been used, i.e., enzymatic darkening due to polyphenols (Esen \& Soost, 1974); analysis by gas chromatography (Weinbaum et al., 1982); and isoenzyme pattern analysis (Moore \& Castle, 1988 Anderson et al., 1991). Nevertheless, since products of gene expression were used in those cases, results may be influenced by the environment, as well as by the stage of development of the plant and its organs, thus making this method unreliable for zygotic seedling identification. Recently, molecular techniques such as RAPD (Randomly Amplified Polymorphic DNA) are available. In citrus, they have been used to study the genetic origin of 'Cravo' lemon plants which had been visually selected as possible hybrids (Cristofani \& Machado, 1998); to identify the mandarin 'Montenegrina' x mandarin 'King' (Citrus spp.) hybrids (Bastianel et al., 1998); and to study genetic diversity and to identify interspecific crosses such as 'Volkamerian' lemon x 'Cravo' lemon (Vilarinhos et al., 2000).

The objectives of this work were to evaluate the frequency of polyembryony, and to identify zygotic and nucellar seedlings of Citrus volkameriana using RAPD.

\section{Material and Methods}

\section{Plant material}

Mature, open pollinated fruits of C. volkameriana were harvested in the autumn-winter of 1998-1999, 1999
2000 and 2000-2001. The fruit were collected from clonal plants growing in a citrus orchard of seven years old located in Cazones de Herrera, Veracruz, México. In every harvest, 60 fruits were collected, their seeds removed, washed in $2 \%$ sodium hypochloride with five drops of liquid detergent, and stirred for $15 \mathrm{~min}$ in order to remove mucilaginous testa.

\section{Morphological characteristics in fruits and} polyembryony

For all 180 fruits, the following variables were evaluated: fruit weight $(\mathrm{g})$; equatorial diameter $(\mathrm{cm})$; number of carpels; total number of seeds (full and empty seeds). Full seeds were identified as those which the embryo sack was filled with the embryos.

To study polyembryony, five seeds per fruit were randomly selected for a total of 300 for each harvest year. The testa and endotegmen were removed from each seed and the embryos were separated under 10x magnification. The number of embryos per seed and the embryo's length (from the tip of the radicle to the end of the largest cotyledon) were recorded.

\section{Experimental design and statistical analysis}

A completely random experimental design was used, with three treatments (years) and three replications, each with 20 fruits and 100 seeds. Data were analyzed using the SAS Statistical Package (SAS Institute Inc., 1988). The means were separated using Tukeys' Multiple Gama procedure $(\mathrm{P} \leq 0.05)$. In addition a variable correlation and percentage of seeds with $1,2,3, \ldots$ n embryos were utilized.

\section{Identification of zygotic and nucellar seedlings}

Five seeds were extracted from each fruit in order to culture the embryos of 25 polyembryonic and 8 monoembryonic seeds. The seeds were placed in a precipitate glass containing $50 \mathrm{~mL}$ of $2 \%$ sodium hypochloride with five drops of liquid detergent. The seeds were stirred for $15 \mathrm{~min}$ and rinsed five times with distilled sterilized water. After the fibrous testa and endotegmen were removed, each embryo was separated and sown in a baby food jar with $40 \mathrm{~mL}$ of medium. The embryos were arranged counter clockwise, per size and according to the seed micropyle (farthest to closest) and cultivated on Villegas et al. (1992) medium. The medium was supplemented with $40 \mathrm{~g} \mathrm{~L}^{-1}$ sucrose, $0.1 \mathrm{mg} \mathrm{L}^{-1}$ kinetin, $0.1 \mathrm{mg} \mathrm{L}^{-1} 3$-indol butyric acid, and $6 \mathrm{~g} \mathrm{~L}^{-1}$ of agar. The $\mathrm{pH}$ was adjusted to 5.7 using $1 \mathrm{~N} \mathrm{NaOH}$ and $1 \mathrm{~N} \mathrm{HCl}$ and medium autoclaved to $121^{\circ} \mathrm{C}$ for $15 \mathrm{~min}$. 
The cultures were placed in a culture room with a photoperiod of 16 hours light, a temperature of $26 \pm 2^{\circ} \mathrm{C}$ and a light intensity of $30 \mu \mathrm{mol} \mathrm{m} \mathrm{m}^{-2} \mathrm{~s}^{-1}$ (photosynthetic active radiation).

The seedlings were transferred to fresh medium every two months until they were large enough to obtain $100 \mathrm{mg}$ of leaves (3 months for large embryos, 6-9 mm, and 6 months for small embryos, $3-5 \mathrm{~mm}$ ).

\section{Collecting plant material}

Young, fully expanded leaves were taken at random from the mother plant (from which the fruits were collected), placed in plastic bags and kept at $-20^{\circ} \mathrm{C}$ until DNA extraction. Leaves were also taken from seedlings grown in vitro, but only from those seeds whose all embryos developed. Eight seedlings from monoembryonic seeds and 27 from polyembryonic seeds were studied. The leaves were collected in sterile conditions, in order to conserve the seedlings in vitro, and were later placed in $1.5 \mathrm{~mL}$ eppendorf tubes, labeled and placed on ice until DNA extraction.

\section{Isolation of genomic DNA}

Plant DNA extraction methodology was as previously described by Machado et al. (1996), with the modifications indicated in order to obtain high molecular weight DNA. Leaf samples $(100 \mathrm{mg})$ were taken from mother plants, seedlings from monoembryonic seeds and 27-100 mg of leaves of seedlings from polyembryonic seeds. For DNA extraction, the powder from samples was homogenized with $800 \mu \mathrm{L}$ of CTAB extraction buffer and centrifuged at $11,750 \mathrm{~g}$ for $8 \mathrm{~min}$. For DNA precipitation, the samples were centrifuged at $8,160 \mathrm{~g}$ for 15 minutes. The supernatant was discarded and the pellet obtained was dissolved in $400 \mu \mathrm{L}$ TE solution (10 mM Tris-HCl pH 8.0, 1 mM EDTA, $1 \mathrm{M} \mathrm{NaCl}$ ) at $65^{\circ} \mathrm{C}$. After cooling the mixture to room temperature, the DNA was precipitated in 2 volumes of $100 \%$ cold ethanol, stirring slowly, stored at $-20^{\circ} \mathrm{C}$ during $30 \mathrm{~min}$ and after centrifuging at $11,750 \mathrm{~g}$ for $5 \mathrm{~min}$, the supernatant was discarded. The DNA was washed with $700 \mu \mathrm{L} 70 \%$ cold ethanol and centrifuged at $11,750 \mathrm{~g}$ for $5 \mathrm{~min}$. Two washings were carried out with $400 \mu \mathrm{L}$ $100 \%$ cold ethanol and subsequently centrifuged at $11,750 \mathrm{~g}$ for $5 \mathrm{~min}$. The resulting DNA was dissolved in $25 \mu \mathrm{L}$ of $0.1 \mathrm{TE}(1 \mathrm{mM}$ Tris- $\mathrm{HCl} \mathrm{pH} 8.0,0.1 \mathrm{mM}$ EDTA) with $10 \mathrm{ng} \mu \mathrm{L}^{-1}$ of ribonuclease, heated at $37^{\circ} \mathrm{C}$ for $40 \mathrm{~min}$ and stored at $-20^{\circ} \mathrm{C}$, until use.
The integrity of DNA was estimated by electrophoretic separation of the DNA samples in agarose gel at $1 \%$. Electrophoresis was carried out in a chamber Model \#B1 at $70 \mathrm{~V}$ with the buffer TAE (0.04 M Trisbase, glacial acetic acid, $1 \mathrm{mM}$ EDTA) for 2 hours. Afterwards, the gel was stained with $1 \mu \mathrm{g} \mathrm{mL}-1$ ethidium bromide for 15 minutes. The concentration and pureness were quantified using an ultraviolet light spectrophotometer. Purity was evaluated as the proportion between readings at 260 and $280 \mathrm{~nm}$.

\section{RAPD analysis}

Primers were selected based on DNA amplification of mother plants, a monoembryonic seedling and four seedlings from a polyembryonic seeds. Ten primers with a random sequence of ten nucleotides and one with eight nucleotides from Operon Technologies Inc. (Table 1). The reaction mixture contained $10 \mu \mathrm{L}$ of dNTPs $(5 \mu \mathrm{M}$ of each dNTP), $2.5 \mu \mathrm{L}$ buffer PCR (10x), $1.5 \mu \mathrm{L} \mathrm{MgCl}_{2}$ (75 mM), $2.0 \mu \mathrm{L}$ primer (20 pmol), $0.3 \mu \mathrm{L}$ (1.5 U) DNA native Taq polymerase, $4 \mu \mathrm{L} \mathrm{DNA} \mathrm{(80} \mathrm{ng)} \mathrm{adjusting} \mathrm{to}$ $25 \mu \mathrm{L}$ with $4.7 \mu \mathrm{L}$ sterilized deionized water. The program used for amplification by polymerase chain reaction (PCR), performed in a programmed thermocycler, consisted of an initial DNA predenaturalization cycle at $94^{\circ} \mathrm{C}$ for $4 \mathrm{~min}$ and 35 integrated cycles for the following stages: $94^{\circ} \mathrm{C}$ for $1 \mathrm{~min}$ for separating DNA stands, $36^{\circ} \mathrm{C}$ for $1 \mathrm{~min}$ for primer alignment, $72^{\circ} \mathrm{C}$ for $2 \mathrm{~min}$ for extension or polymerization, and a final extension cycle at $72^{\circ} \mathrm{C}$ for $10 \mathrm{~min}$. When the program for the amplification of the DNA samples was completed, they were stored at $-20^{\circ} \mathrm{C}$.

The separation of amplified fragments was performed by electrophoresis in $1.5 \%$ (w/v) agarose gel. The gel was documented using EDAS (Electrophoresis Documentation and Analysis System). The size of the DNA fragments produced by the RAPD was calculated using the Labworks 4.0 program.

Table 1. Random primers proved for Citrus volkameriana DNA amplification.

\begin{tabular}{lccc}
\hline Primer & Base sequences (5'- 3’) & Primer & Base sequences (5'- $3^{\prime}$ ) \\
\hline OPI1 & ACA TGC CGT G & OPB07 & GGT GAC GCA G \\
OPH15 & AAT GGC GCA G & OPB08 & GTC CAC ACG G \\
P140 & AGG TCA CTG A & OPB12 & CCT TGA CGC A \\
P141 & GGG GTT GAC C & OPB17 & AGG GAA CGA G \\
OPBO2 & TGA TCC CTG G & OPM05 & CGC GGC CA \\
OPB05 & TGC GCC CTT C & & \\
\hline
\end{tabular}


Molecular data analysis

The molecular data analysis for the identification of the origin of the seedlings was carried out by comparing band patterns generated by the mother plant, with those generated by each seedling. The bands produced for each DNA sample by five primers were considered polymorphic when they were absent or present in at least one of the seedlings evaluated.

\section{Results and Discussion}

Morphological characteristics of the fruit and their correlation with polyembryony

The fruits harvested in winter 1999-2000 displayed greater weight and equatorial diameter than in the other two harvest years. The number of seeds, total and full seeds, were fewer in the 1998-1999 harvest, whereas the carpels per fruit did not significantly differ among years (Table 2). The number of carpels per fruit has been reported to vary among species: oranges may have from 9 to 11 , lemons 8 to 10 , and grapefruits, 12 to 15 (Loussert, 1992).

The average number of seeds, full and total seeds (35 and 29), observed in this research were greater to those previously reported by Gravina (1989), who found an average of 19 seeds in an Experimental Station in Tecoman, Colima (INIFAP) Mexico.

The fact that fruit characteristics differ according to geographic and year of harvest shows that these characteristics are influenced by environmental conditions that may be different in each location or year of evaluation. Therefore rootstocks should be evaluated in areas where seed production is desired, in order to establish a production program.

Polyembryony in C. volkameriana varied from one year to the next and more embryos per seed were found in fruits harvested in 2000-2001 (Table 3). The number of embryos per seed varied between 1 and 6 , averaging 1.5 , this last one was similar to that obtained by Campos (1986) in Cuba. Considering the classification quoted by Prates \& Pompeu Junior (1981), C. volkameriana would be into the average polyembryony category (30 to $60 \%$ polyembryony).

The results differ from those of Soares Filho et al. (1995), who observed 1 to 12 embryos per seed, with an average of 2.7 embryos and $7.7 \%$ of the seeds showed polyembryony in seeds harvested in Cruz das Almas, Bahia, Brazil.

Polyembryony is also affected by the type of pollinator (Soares Filho et al., 1995), amount and pollen viability available, plant nutrition, air temperature, environmental and soil humidity, and speed of the wind. Dhillon et al. (1993) reported that adventitious embryos developed into globular or early cotyledon stages in the absence of pollination, but the embryos require the endosperm in order to grow, making pollination and fertilization necessary for the development of the polyembryonic seeds. Therefore any factor that affects pollination, fertilization or seed development will also affect the percentage of polyembryony and embryo number per seed. The difference in results obtained in various locations shows the importance of determining the

Table 2. Morphological characteristics of Citrus volkameriana fruits evaluated in three harvest years ${ }^{(1)}$.

\begin{tabular}{lccccc}
\hline Harvest year & Fruit weight $(\mathrm{g})$ & Equatorial diameter $(\mathrm{cm})$ & Carpels $(\mathrm{No})$ & Total seeds $(\mathrm{No})$ & Full seeds $($ No) \\
\hline $1998-1999$ & $141 \mathrm{c}$ & $6.4 \mathrm{~b}$ & $9.3 \mathrm{a}$ & $27.9 \mathrm{~b}$ & $24.7 \mathrm{~b}$ \\
$1999-2000$ & $176 \mathrm{a}$ & $6.9 \mathrm{a}$ & $9.2 \mathrm{a}$ & $37.7 \mathrm{a}$ & $31.4 \mathrm{a}$ \\
$2000-2001$ & $157 \mathrm{~b}$ & $6.5 \mathrm{~b}$ & $9.2 \mathrm{a}$ & $39.9 \mathrm{a}$ & $32.3 \mathrm{a}$ \\
\hline DMS $(\mathrm{P} \leq 0.05)$ & 12.8 & 0.23 & 0.53 & 3.1 & 2.9 \\
\hline
\end{tabular}

${ }^{(1)}$ Means in each column followed by different letters are significantly different ( $\left.\mathrm{P} \leq 0.05\right)$ according to Tukey test.

Table 3. Percentage of seeds of Citrus volkameriana with more than one embryo, evaluated in three harvest years.

\begin{tabular}{lcccccccc}
\hline Harvest year & \multicolumn{9}{c}{ Frequency of seeds with the following number of embryos } & $\mathrm{P}^{(1)}$ & \multirow{2}{*}{$\mathrm{S} / \mathrm{E}^{(2)}$} \\
\cline { 2 - 9 } & 1 & 2 & 3 & 4 & 5 & 6 & & \\
\hline $1998-1999$ & 69.1 & 22.6 & 6.0 & 2.1 & 0.2 & - & 30.9 & 1.3 \\
$1999-2000$ & 55.2 & 27.6 & 11.3 & 4.9 & 0.9 & - & 44.8 & 1.6 \\
$2000-2001$ & 45.6 & 30.5 & 15.4 & 5.5 & 2.7 & 0.3 & 54.4 & 1.8 \\
\hline
\end{tabular}

(1)P: percentage of polyembryonic seeds. (2)S/E: average number of embryos per seed. 
characteristics of polyembryony in each country where seeds from rootstocks are going to be produced.

Embryo length is an aspect which has not been taken into account in previous studies; nonetheless, it is important that this variable be determined, since it is related to the embryo's germination capacity. There is a relationship between the size of the embryos and their origin. Larger embryos developed from monoembryonic seeds $(10$ to $11 \mathrm{~mm})$, whereas, the largest embryos were between 8 and $9 \mathrm{~mm}$ in polyembryonic seeds.

The number of embryos per seed was observed to be inversely proportional to the length of each embryo, confirming Porto \& Moreira (1978) and Cameron \& Soost (1987).

Correlation of fruit characteristics with polyembryony

Although most of the fruit characteristics did not show a significant correlation with polyembryony, the number of seeds per fruit and full seeds were significant with the number of embryos per seed, as well as with embryo length (Table 4). The fruits with many seeds had more small embryos than fruits with few seeds, which produced a few large embryos.

The number of embryos per seed was negatively correlated with embryo length, implying that as the number of embryos per seed increased, embryo size decreased. This may be due to competition for nutrients among embryos. Determining a relationship between fruit

Table 4. Correlation of fruit characteristics with polyembryony in Citrus volkameriana.

\begin{tabular}{lcc}
\hline Fruits characteristics & Number of embryos & Embryo length \\
\hline Fruit weight & $0.053^{\text {ns }}$ & $0.063^{\text {ns }}$ \\
Equatorial diameter & $0.02^{\text {ns }}$ & $0.041^{\text {ns }}$ \\
Carpel number & $-0.123^{\text {ns }}$ & $0.126^{\text {ns }}$ \\
Total seeds per fruit & $0.264^{* *}$ & $-0.226^{* *}$ \\
Full seeds & $0.190^{*}$ & $-0.171^{*}$ \\
Embryo number & & $-0.830^{* *}$
\end{tabular}

characteristics and polyembryony is important to predict which fruits may contain more nucellar seedlings. The C. volkameriana morphological characteristics of fruits were not correlated and therefore unreliable indicators of the degree of polyembryony of the seeds. By contrast, a high correlation value between morphological characteristics of the fruit and polyembryony has been observed in mandarin 'Cleopatra' (Andrade, 2002).

\section{Identification of zygotic and nucellar seedlings} using RAPD

Polymorphism was clearly observed with four of the five primers used. A total of 61 bands was generated, and $39 \%$ were polymorphic. With primers OPB07, OPI11, and P141, an average of 12 bands were generated per primer. However, none of the eight bands amplified by OPM05 showed polymorphism (Table 5). The size of the polymorphic fragments varied from 361 to 2,124 bp (Figure 1).

Six and five zygotic seedlings were reveled by markers OPI11 171 and OPB07 1660 , respectively. The band pattern in zygotic plants was different from that of the mother plant, due mostly to the absence of some fragments, as well as to the presence of OPB07 785 and OPB07 410 markers (Figure 1). With primers OPI11, P141 and OPB07 zygotic seedlings among 27 developed embryos obtained from nine polyembryonic seeds and seven zygotic seedlings from eight monoembryonic seeds were identified. Primer OPB07 generated sufficient polymorphism in 12 zygotic seedlings (Table 6). No single primer was able to identify all 12 zygotic seedlings. This coincides with results obtained by Vilarinhos et al. (2000), who identified 12 'Volkameriano' lemon x 'Cravo' lemon hybrid plants, previously labeled as zygotic due to morphological characteristics; out of the 20 primers tested only six produced banding patterns that discriminated between the parents. Nevertheless,

Table 5. Level of polymorphism achieved with five RAPD primers in Citrus volkameriana.

\begin{tabular}{lccccc}
\hline Primer & Total bands amplified & Polymorphic bands & Polymorphism (\%) & \multicolumn{2}{c}{ Zygotic seedlings ${ }^{(1)}$} \\
\cline { 3 - 6 } & & & & PS & MS \\
\hline OP11 & 15 & 7 & 46.6 & $4 / 27$ & $7 / 8$ \\
OPH15 & 10 & 4 & 20.0 & $2 / 27$ & $3 / 8$ \\
P141 & 9 & 0 & 44.4 & $5 / 27$ & $3 / 8$ \\
OPM05 & 8 & 11 & 0.0 & $5 / 27$ & $0 / 8$ \\
OPB07 & 19 & 24 & 57.8 & $5 / 27$ & $7 / 8$ \\
\hline Total & 61 & & 39.3 & $7 / 27$ & $7 / 8$ \\
\hline
\end{tabular}

(1) Number of zygotic seedlings that could be discerned by each primer over the total number of seedlings tested; PS: from polyembryonic seeds; MS: from monoembryonic seeds. 
none of the 20 primers used by Vilarinhos et al. (2000) reveled all 12 hybrids, although they could be identified with OPB05 and OPB01 together.

In monoembryonic seeds, $87.5 \%(7 / 8)$ out of all seedlings were zygotic. Seedlings displayed the same banding pattern as the DNA sample from the mother plant with the five primers used, which possibly shows that its origin was nucellar since those seedlings reproduced the genotype from the female plant (Frost, 1926; Campos, 1986; Dhillon et al., 1993) otherwise the five primers were insufficient to differentiate this seedling from the mother plant.

For polyembryonic seeds, out of 27 seedlings studied, seven showed a banding pattern different from that of
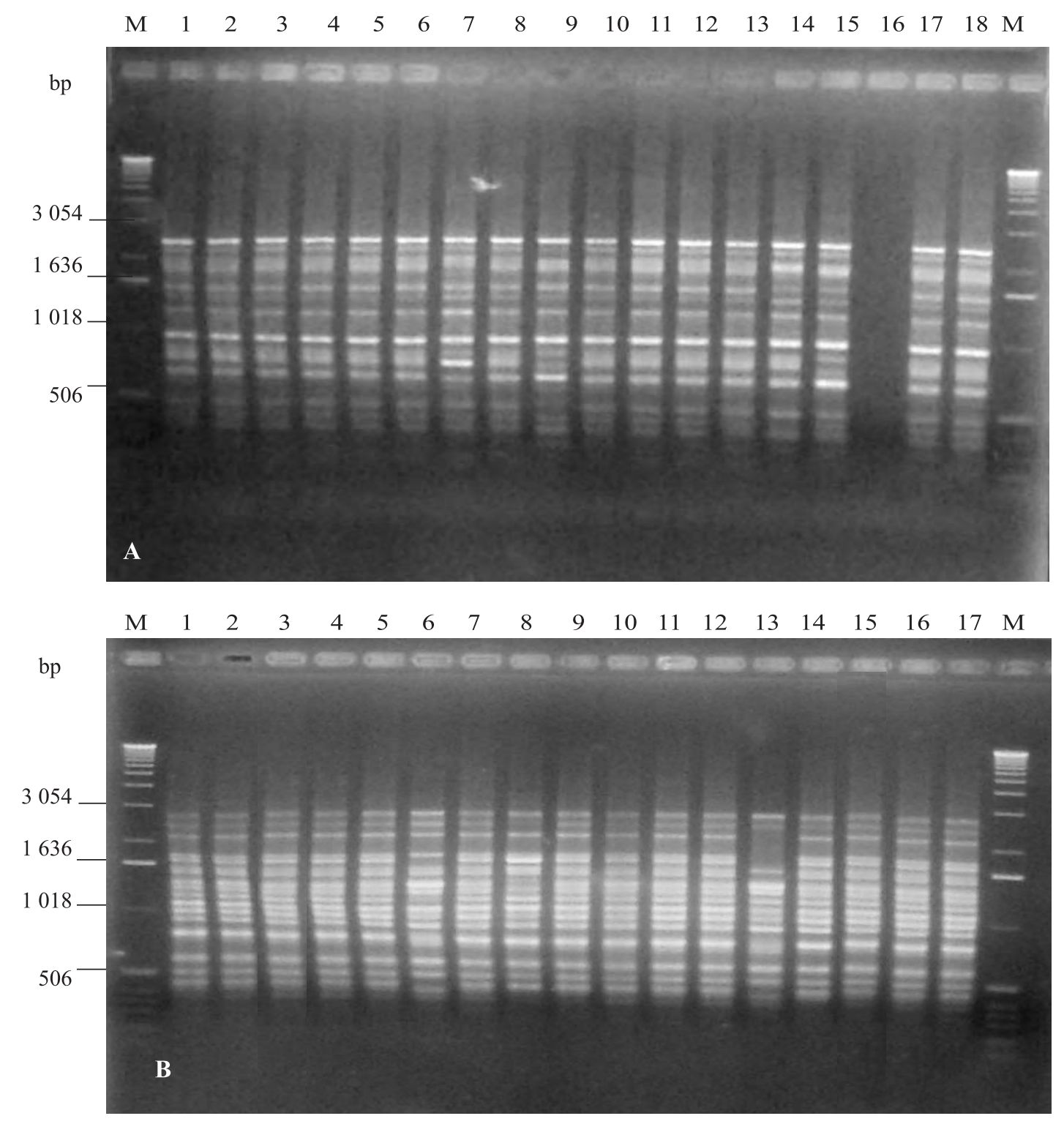

Figure 1. DNA amplifications of sixten C. volkameriana seedlings from polyembryonic seeds. A) OPI11. M: molecular weight markers (1 kb DNA Ladder); 1 and 2: mother plant; 3 to 5: seedlings 1 to 3 of seed number $1 ; 6$ and 7: seedlings 1 and 2 of seed number $2 ; 8$ to 12: seedlings 1 to 5 of seed number $3 ; 13$ and 14: seedlings 1 and 2 of seed number 4; 15 to 18: seedlings 1 to 4 of seed number 5. B) OPB07. M: molecular weight markers ( $1 \mathrm{~kb}$ DNA Ladder); 1: mother plant; 2 to 4 : seedlings 1 to 3 of seed number 1; 5 and 6: seedlings 1 and 2 of seed number 2; 7 to 11: seedlings 1 to 5 of seed number $3 ; 12$ and 13: seedlings 1 and 2 of seed number $4 ; 14$ to 17 : sendlings 1 to 4 of seed number 5 . 
the mother plant, indicating zygotic origin. However, nine out of the 27 seedlings were expected to be zygotic because these plants were obtained from nine seeds each expected to contain one zygotic embryo (Frost, 1926; Koltunow et al., 1996). Assuming that there were nine zygotic seedlings, $78 \%$ of them were identified. Among the polyembryonically originated seedlings, $26 \%$ were zygotic. These results were similar to those reported by Moore \& Castle (1988), who identified 24\% zygotic 'Volkamerian' lemon seedlings using isoenzyme based markers.

For C. volkameriana rootstock, García et al. (1999) reported only $22 \%$ zygotic seedlings from seeds derived from open pollination, and $60 \%$ of zygotic seedlings were obtained after pollination with Poncious trifoliata. The authors suggest that when the zygotic embryo is a hybrid, it may be more vigorous, and hence compete better with nucellar embryos, whereas zygotic embryos produced by self-pollination are less vigorous and may not be competitive with nucellar ones.

Regarding the location of embryos in the seed for $43 \%$ of the polyembryonic seeds ( 3 of 7 ), embryos located at the micropylar end and the smallest size embryos were zygotic (Table 6). These embryos did not develop seedlings in the greenhouse or nursery. This lack of growth may be due to dehydration, or to the lack of reserve material. In $44 \%$ of the polyembryonic seeds (4 of 9), the sexual seedling grew from a large or medium size embryo, which was not located at the micropylar end (Table 5). By contrast Thakur \& Bojwa (1971)

Table 6. Zygotic or nucellar origin of Citrus volkameriana seedlings by mean RAPD with four primers as a function of embryo location within polyembryonic seed and embryo size.

\begin{tabular}{|c|c|c|c|c|c|c|}
\hline Seed (No) & Seedling (No) & Size of embryo that originate each seedling $(\mathrm{mm})$ & OPI11 & OPH15 & P141 & OPB07 \\
\hline \multicolumn{7}{|c|}{ Polyembryonic seeds ${ }^{(1)}$} \\
\hline \multirow[t]{2}{*}{1} & 1 & 9 & $\mathrm{~N}$ & $\mathrm{~N}$ & $\mathrm{~N}$ & $\mathrm{~N}$ \\
\hline & 2 & $2(\mathrm{M})$ & $\mathrm{N}$ & $\mathrm{N}$ & $\mathrm{N}$ & $\mathrm{Z}$ \\
\hline \multirow[t]{5}{*}{2} & 1 & 9 & $\mathrm{~N}$ & $\mathrm{~N}$ & $\mathrm{~N}$ & $\mathrm{~N}$ \\
\hline & 2 & 6 & $\mathrm{Z}$ & $\mathrm{N}$ & $\mathrm{Z}$ & $\mathrm{Z}$ \\
\hline & 3 & 5 & $\mathrm{~N}$ & $\mathrm{~N}$ & $\mathrm{~N}$ & $\mathrm{~N}$ \\
\hline & 4 & 4 & $\mathrm{~N}$ & $\mathrm{~N}$ & $\mathrm{~N}$ & $\mathrm{~N}$ \\
\hline & 5 & $3(\mathrm{M})$ & $\mathrm{N}$ & $\mathrm{N}$ & $\mathrm{N}$ & $\mathrm{N}$ \\
\hline \multirow[t]{2}{*}{3} & 1 & 9 & $\mathrm{~N}$ & $\mathrm{~N}$ & $\mathrm{~N}$ & $\mathrm{~N}$ \\
\hline & 2 & $2(\mathrm{M})$ & $\mathrm{Z}$ & $\mathrm{Z}$ & $\mathrm{Z}$ & $\mathrm{Z}$ \\
\hline \multirow[t]{4}{*}{4} & 1 & 8 & $\mathrm{Z}$ & $\mathrm{N}$ & $\mathrm{Z}$ & $\mathrm{N}$ \\
\hline & 2 & 6 & $\mathrm{~N}$ & $\mathrm{~N}$ & $\mathrm{~N}$ & $\mathrm{~N}$ \\
\hline & 3 & 5 & $\mathrm{~N}$ & $\mathrm{~N}$ & $\mathrm{~N}$ & $\mathrm{~N}$ \\
\hline & 4 & $3(\mathrm{M})$ & $\mathrm{N}$ & $\mathrm{N}$ & $\mathrm{N}$ & $\mathrm{N}$ \\
\hline \multirow[t]{4}{*}{5} & 1 & 9 & $\mathrm{~N}$ & $\mathrm{~N}$ & $\mathrm{Z}$ & $\mathrm{Z}$ \\
\hline & 2 & 6 & $\mathrm{~N}$ & $\mathrm{~N}$ & $\mathrm{~N}$ & $\mathrm{~N}$ \\
\hline & 3 & 5 & $\mathrm{~N}$ & $\mathrm{~N}$ & $\mathrm{~N}$ & $\mathrm{~N}$ \\
\hline & 4 & $2(\mathrm{M})$ & $\mathrm{N}$ & $\mathrm{N}$ & $\mathrm{N}$ & $\mathrm{N}$ \\
\hline \multirow[t]{3}{*}{6} & 1 & 9 & $\mathrm{~N}$ & $\mathrm{~N}$ & $\mathrm{~N}$ & $\mathrm{~N}$ \\
\hline & 2 & 6 & $\mathrm{~N}$ & Z & $\mathrm{Z}$ & Z \\
\hline & 3 & $3(\mathrm{M})$ & $\mathrm{N}$ & $\mathrm{N}$ & $\mathrm{N}$ & $\mathrm{N}$ \\
\hline \multirow[t]{11}{*}{7} & 1 & 8 & $\mathrm{~N}$ & $\mathrm{~N}$ & $\mathrm{~N}$ & $\mathrm{~N}$ \\
\hline & 2 & $2(\mathrm{M})$ & $\mathrm{Z}$ & $\mathrm{N}$ & $\mathrm{N}$ & $\mathrm{N}$ \\
\hline & \multicolumn{6}{|c|}{ Monoembryonic seeds } \\
\hline & 1 & 10 & $\mathrm{~N}$ & $\mathrm{~N}$ & $\mathrm{~N}$ & $\mathrm{~N}$ \\
\hline & 2 & 10 & $\mathrm{Z}$ & $\mathrm{Z}$ & $\mathrm{N}$ & $\mathrm{Z}$ \\
\hline & 3 & 10 & $\mathrm{Z}$ & $\mathrm{N}$ & $\mathrm{N}$ & Z \\
\hline & 4 & 9 & $\mathrm{Z}$ & $\mathrm{N}$ & $\mathrm{N}$ & $\mathrm{Z}$ \\
\hline & 5 & 10 & $\mathrm{Z}$ & $\mathrm{N}$ & $\mathrm{Z}$ & $\mathrm{Z}$ \\
\hline & 6 & 10 & $\mathrm{Z}$ & $\mathrm{N}$ & $\mathrm{Z}$ & $\mathrm{Z}$ \\
\hline & 7 & 10 & $\mathrm{Z}$ & $\mathrm{Z}$ & $\mathrm{N}$ & Z \\
\hline & 8 & 10 & $\mathrm{Z}$ & $\mathrm{N}$ & $\mathrm{Z}$ & $\mathrm{Z}$ \\
\hline
\end{tabular}

(1)M: micropylar embryo; N: nucellar origin; Z: zygotic origin. 
observed that the zygotic embryo was consistently located at the micropylar end of the seed.

In C. volkameriana, $88 \%$ of seedlings from monoembryonic seeds and $26 \%$ of seedlings from polyembryonic seeds were classified as zygotic by the RAPD technique. Cristofani \& Machado (1998) reported $6 \%$ zygotic seedlings of 'Cravo' lemon in a sample of 50 plants taken from a population of 576 produced in a greenhouse. The difference in these results is due to the fact that, in the present research, embryos of each seed were separated and cultivated in vitro, using a baby food jar for each seed, which allowed us to obtain a seedling from every embryo. Previous studies employed seedlings grown in different environment, i.e., greenhouses (Cristofani \& Machado, 1998; Bastianel, 1999), germination containers (Moore \& Castle, 1988), pots (Ashari et al., 1988), or germinating the seed in vitro (Bastianel et al., 1998). When germination is carried out in a substrate, not all embryos within a seed develop into seedlings, since many of them are dehydrated or do not have enough reserve material in order to seedling growth and development.

\section{Conclusions}

1. Environmental conditions of the harvest year affect polyembryony in Citrus volkameriana.

2. Morphological characteristics of the fruit are not reliable to indicate the degree of polyembryony in this rootstock.

3. Seedlings classified as zygotic have a different RAPD profile from that of the mother plant or nucellar seedlings.

4. Small embryos located at the micropylar end of the seed do not always produce zygotic seedlings.

\section{References}

ANDERSON, C.M.; CASTLE, W.S.; MOORE, G.A. Isozymic identification of zygotic seedlings in Swingle citrumelo Citrus paradisi x Poncirus trifoliata nursery and field populations. Journal of the American Society for Horticultural Science, v.116, p.322-326, 1991.

ANDRADE, R.M. Poliembrionía e identificación de plántulas cigóticas y nucelares de tres portainjertos y un cultivar de cítricos mediante RAPD's. 2002. 122p. Tesis (Doctorado) - Colegio de Postgraduados, Montecillo.

ASHARI, S.; ASPINALL, D.; SEDGLEY, M. Discrimination of zygotic and nucellar seedlings of five polyembryonic citrus rootstocks by isozyme analysis and seedling morphology. Journal of Horticultural Science, v.63, p.695-703, 1988.
BASTIANEL, M. Análise de uma população segregante de tangerineira 'Lee' [Citrus clementina Hort. ex Tanaka $\mathrm{x}(C$. tangerina Hort. ex Tanaka $\mathrm{C}$. paradisi Macf.)] através de RAPD e marcadores morfológicos. 1999. 95p. Dissertação (Mestrado) Universidade Federal do Rio Grande do Sul, Porto Alegre.

BASTIANEL, M.; SCHWARDZ, S.F.; COLETTA FILHO, H.D.; LIN, L.L.; MACHADO, M.; KOLLER, O.C. Identification of zygotic and nucellar tangerine seedlings (Citrus spp.) using RAPD. Genetics and Molecular Biology, v.21, p.123-127, 1998.

CAMERON, J.W.; SOOST, R.K. Cítricos. In: FERWERDA, F.P.; WIT, F. (Ed.). Genotecnia de cultivos tropicales perenes. México: AGT, 1987. p.156-191.

CAMPOS, A. Contribución al estudio de la poliembrionía de algunos géneros de Rutaceae. In: SIMPOSIO INTERNACIONAL DE CITRICULTURA TROPICAL, 1986, Havana. Memórias. Havana: Ministerio de Educación Superior, 1986. v.1, p.57-59.

CASTLE, W.S. Patrones y variedades. In: SEMINARIO DE CITRICULTURA, 1987, Mérida. Memorias. Mérida: Banco de México; Fideicomisos Instituidos en Relación con la Agricultura, 1987. p.45-60.

CRISTOFANI, M.; MACHADO, M.A. Utilização de marcadores moleculares na identificação de plântulas zigóticas e nucelares em sementeira de limão 'Cravo'. Laranja, v.19, p.147-158, 1998.

DHILLON, R.S.; KAUNDAL, G.S ; CHEEMA, S.S. Nucellar embryony for propagating Citrus. Indian Horticulture, v.38, p.4445, 1993.

ESEN, A.; SOOST, R.K. Inherence of browning of young-shoot extracts of Citrus. Journal of Heredity, v.65, p.97-100, 1974.

FROST, H.B. Polyembryony, heterozygosis and chimeras in citrus. Hilgardia, v.1, p.365-402, 1926.

GARCÍA, R.; ASÍNS, M.J.; FORNER, J.; CARBONELL, E.A. Genetic analysis of apomixis in Citrus and Poncirus by molecular markers. Theoretical and Applied Genetics, v.99, p.511-518, 1999. GRAVINA, T.A. Características viveristas en nueve portainjertos de cítricos. Revista Chapingo, v.13/14, p.33-36, 1989.

KOLTUNOW, A.M.; HIDAKA, T.; ROBINSON, S.P. Polyembryony in Citrus. Plant Physiology, v.110, p.599-609, 1996. LOUSSERT, R. Los agrios. Traducido al español por Vicente Almela Orenga y Manuel Agusti Fonfria. Madrid: Mundi, 1992. 319p.

MACHADO, M.A.; COLETTA FILHO, H.D.; TARGON, M.L.P.N.; POMPEU JUNIOR, J. Genetic relationship of Mediterranean mandarins (Citrus deliciosa Tenore) using RAPD markers. Euphytica, v.92, p.321-326, 1996.

MOORE, G.A.; CASTLE, W.S. Morphological and isozymic analysis of open-pollinated citrus rootstock populations. Journal of Heredity, v.79, p.59-63, 1988.

POMPEU JUNIOR, J. Porta-enxertos. In: RODRÍGUEZ, O.; VIÉGAS, F.; POMPEU JUNIOR, J.; AMARO, A.A. (Ed.). Citricultura brasileira 1. 2.ed. Campinas: Fundação Cargill, 1991. p.265-280 
PORTO M.O. de; MOREIRA, C.S. Influência do tamanho de sementes na viabilidade, poliembrionia e desenvolvimiento de "seedlings" de limoeiro 'Cravo' (Citrus limonia, Osbeck). Revist Brasileira de Fruticultura, v.1, p.25-33, 1978

PRATES, H.S.; POMPEU JUNIOR, J. Determinação preliminar de poliembrionia e número médio de embriões, em sementes de Citrus e afins, do banco ativo de germoplasma do Instituto Agronômico de Campinas. In: CONGRESSO BRASILEIRO DE FRUTICULTURA 6., 1981, Recife. Anais. Recife: Sociedade Brasileira de Fruticultura, 1981. v.2, p.563-568.

SAS INSTITUTE INC. (Cary, United States). SAS/STAT user's guide. $6^{\text {th }}$ ed. Cary, 1988. 1028p.

SOARES FILHO, W dos S.; LEE, L.M.; CUNHA SOBRINHO, A.P da. Influence of pollinators on polyembryony in Citrus. Acta Horticulturae, n.403, p.256-265, 1995.

THAKUR, D.R.; BOJWA, B.S. Extent of polyembryony in some species and varieties of citrus. Indian Journal of Horticulture, v.2, p.25-28, 1971 .
VILARINHOS, A.D. PEREIRA, V.C.H.; SOARES FILHO, W.S.; NICKEL, O.; OLIVEIRA, R.P. de. Marcadores RAPD na avaliação da diversidade genética e na identificação de híbridos interespecíficos de citros. Revista Brasileira de Fruticultura, v.22, p.14-19, 2000.

VILLEGAS, M.A.; MAZUELOS, C.; TRONCOSO, A. Influence of $\mathrm{N}-\mathrm{NO}_{3}$ and $\mathrm{N}-\mathrm{NH}_{4}$ on the mineral composition of grape-vine rootstocks cultured in vitro. Acta Horticulturae, n.300, p.119-121, 1992.

VILLEGAS, M.A.; MORA, A.G.; OCHOA, M.D.L; GUTIÉRREZ, manejo de material tolerante los cítricos. In: EVENTO DE APROBACION Y ACTUALIZACIÓN FITOSANITARIA EN VTC, 1., 2000, Córdoba Veracruz. Memorias. Córdoba Veracruz: Dirección General de Sanidad Vegetal, 2000. p.180-204.

WEINBAUM, S.A.; COHEN, E.; SPIEGEL-ROY, P. Rapid screening of 'Satsuma' mandarin progeny to distinguish nucellar and zygotic seedlings. HortScience, v.17, p.239-240, 1982. 